\title{
Public Procurement, Regional Integration, and the Belt and Road Initiative
}

Tania Ghossein, Bernard Hoekman (D), and Anirudh Shingal

China's Belt and Road Initiative (BRI) is a mechanism through which countries can upgrade connectivity-related infrastructure, including through cross-border projects, complementing traditional sources of finance. An overarching goal of the BRI is to reduce trade costs between China and partner countries, in part by helping to integrate regional markets. The large-scale borrowing associated with BRI projects has given rise to potential debt servicing and sustainability concerns. The rate of return of BRI regional infrastructure projects depends in part on the integrity of public procurement processes and realizing value-for-money objectives. To date BRI projects financed by Chinese institutions have been largely awarded to Chinese companies. Enhancing transparency of BRI procurement processes and international cooperation among countries participating in the BRI would help achieve value for money goals and support the integration of BRI countries.

JEL Codes: F10, F13, H57

Keywords: Belt and Road Initiative, China, public procurement, regional integration, international cooperation.

\section{Introduction}

The ambitious Belt and Road Initiative (BRI) announced by the Chinese government in 2013 seeks to improve connectivity through major infrastructure investments in different parts of Africa, Asia, the Middle East, and Central and Eastern Europe, complemented by projects to enhance productive capacity in participating countries, including economic and trade cooperation zones, trade promotion programs, and trade and transport agreements. At the time of writing China had signed some 200 cooperation agreements with over 130 countries and thirty international organizations to Development / THE WORLD BANK. This is an Open Access article distributed under the terms of the Creative Commons Attribution-NonCommercial-NoDerivs licence (http://creativecommons.org/licenses/by-nc-nd/4.0/), which permits noncommercial reproduction and distribution of the work, in any medium, provided the original work is not altered or transformed in any way, and that the work is properly cited. For commercial reuse, please contact journals.permissions@oup.com doi: 10.1093/wbro/lkab004 
participate in the BRI (Wang and Chen 2020). ${ }^{1}$ The BRI complements other sources of funding to upgrade transport, power, and ICT network infrastructure to improve cross-border (regional) connectivity across several countries (Huang 2016).

The scale of BRI projects in some countries and regions has raised concerns regarding their sustainability and the ability of fiscally vulnerable nations to service and repay the substantial amounts borrowed from Chinese financial institutions. ${ }^{2} \mathrm{~A}$ specific aspect of the BRI that is pertinent to these concerns is the tying of funding for BRI projects to execution by Chinese firms. Most BRI projects are financed by Chinese policy banks, large Chinese state-owned banks, the major state-owned commercial banks, ${ }^{3}$ and the Silk Road Fund (set up in 2014 with an initial total capital of \$40bn) (Chan 2017). Financing by policy banks and entities such as the Silk Road Fund that has a concessional element is tied to the use of Chinese contractors for execution of projects (Zhang and Gutman 2015).

An important factor in assessing the economic implications of BRI projects is the extent to which there is competition among potential suppliers in the award of procurement contracts. There is limited transparency regarding BRI procurement practices and the degree to which there is competition between firms in award of contracts. Ensuring that contracts are allocated through a competitive process increases the likelihood that selected firms are best placed to satisfy the technical criteria at the lowest possible cost, reducing possible negative implications for the overall financial viability of projects. Use of procurement processes that help to assure integrity of projects and attain value for moneys matters for all BRI countries.

The BRI is both an important initiative from the perspective of improving regional connectivity and a potentially significant source of financing for large cross-border infrastructure network projects (World Bank 2019). It has generated substantial attention and interest in participating countries. This makes the BRI a potentially powerful focal point for efforts to improve procurement more generally. Moving BRI procurement processes towards international good practice standards will require policy reform in China as well as upgrading practices in many BRI countries. Putting in place good public procurement regimes is a challenge for all governments. The challenge is even greater when projects span more than one country.

The basic question motivating this paper is what BRI countries could do to adopt good project management and procurement practices. Much can be done through unilateral actions, but these should be complemented by international cooperation. The BRI is to a large extent focused on trade-related investments and seeks to expand commercial exchanges among BRI countries. This suggests that embedding good procurement practices in trade agreements and putting in place mechanisms to enhance the transparency of procurement processes and outcomes on a regional or BRI-wide basis may help to provide a common framework to govern public procurement.

The plan of the paper is as follows. The first section discusses the limited publicly available information on the procurement dimensions of Chinese-funded BRI 
projects. The following sections briefly review good public procurement practices, including for multi-country projects and describe several dimensions of procurement regimes in BRI countries. This is followed by a characterization of the state of play regarding the coverage of procurement in the trade agreements of BRI countries. The penultimate section considers four options to improve BRI-related procurement practices-and procurement more generally. The final section offers some concluding comments.

\section{Public Procurement Dimensions of BRI projects and Chinese Official Financial Assistance}

Little is known about the processes through which firms are selected to execute BRI projects, e.g., the extent to which there is international competitive bidding on projects or, insofar as Chinese-government-funded BRI projects are earmarked for Chinese suppliers, whether there is competition among potential Chinese suppliers. Examples of BRI projects have been reported where it appears that no competition occurred in the selection of the contractor-for instance, reports on Sri Lanka's Hambantota port project suggested that the start-up $\$ 307 \mathrm{~m}$ loan from the China ExportImport Bank only came through once Colombo was ready to accept Beijing's preferred company, China Harbor, as the port's builder (Abi-Habib 2018). In other cases, suppliers are identified through so-called selective tendering processes, where three potential suppliers are identified, of which one is selected. Press reports on several BRI countries suggest that earmarking of projects for Chinese firms may be accompanied by non-transparent procedures that can result in inflated tender prices. ${ }^{4}$

Generating a good picture of procurement under the framework of the BRI is difficult. One reason for this is that the BRI is not well-defined - there is no detailed plan laying out what the initiative covers and what it does not. ${ }^{5}$ The BRI spans very heterogeneous countries and projects. Comprehensive and comparable cross-country data permitting analysis do not exist but the limited publicly accessible information suggests that Chinese suppliers win the majority of BRI projects. The Center for Strategic and International Studies (CSIS) maintains a database of infrastructure and other projects funded by national and multilateral donors (CSIS 2021). Of the 196 projects in this database where the inception date is reported and does not predate the announcement of the BRI, the source of funding is identified in 138 projects and the amount of funding is reported in 82 projects. Of the latter, 43 projects were funded exclusively by Chinese sources and in this limited sample of exclusively Chinese-funded BRI contracts, almost four-fifths (34/43) were allocated to Chinese firms only. ${ }^{6}$ In principle, this high ratio could simply reflect the fact that Chinese firms are very competitive globally. Thus, of all procurement contracts awarded by the World Bank to Chinese firms, over 70 percent are for projects outside China. As of 2013, Chinese 
companies accounted for 42 percent of the total dollar amount of civil works contracts funded by the World Bank in the Africa region (Zhang and Gutman 2015). Hillman (2018) reports that Chinese companies account for somewhat less than onethird of the projects of multilateral development banks. In the case of BRI projects the share of Chinese firms is substantially higher.

While one reason for this may be that Chinese firms are very competitive, their dominance in BRI projects reflects policy as well. The source of financing is a major determinant of how BRI projects are allocated to contractors. Most of the funding for BRI projects (comprising outstanding loans or equity investment) has been provided by the China Development Bank and the Export-Import Bank of China, together providing some 70 percent of the total, with the big four state-owned commercial banks accounting for another fifth (Liu, Zhang and Xiong 2020). Funding by these entities involves both explicit and implicit preferences for Chinese suppliers, ${ }^{7}$ reflecting the fact that funding often has a concessional or preferential element as well as policy objectives that restrict the financing to Chinese contractors (Zhang and Gutman 2015). ${ }^{8}$

In practice there are generally two phases of BRI-project award. The first phase pertains to the selection of a general contractor or supplier by lead Chinese financial institutions. Given that financing generally has some concessional or subsidy elements (e.g., below market interest rates) reflecting the policy objective of the policy banks-including expanding China's exports and commercial footprint in overseas markets in the case of the Export-Import Bank, independent of requirements to tie sourcing of goods and services to Chinese firms - Chinese financial institutions prefer domestic suppliers to reduce technical, financial, and political risks they incur. The suppliers (contractors) may be selected through a single tendering process or be chosen from a small set of potential suppliers. The contractor takes on the operational risk of each BRI project. In general, contractors-including state-owned enterprises (SOEs) - are expected to operate on a commercial basis and thus to generate an adequate rate of return on investment. SOE senior management may face disciplinary action if projects go bad (Deloitte 2018). The rate of return will depend in part on the efficiency of procurement by the selected lead contractor, which will need to buy equipment, materials, and services. It is at this second stage that opportunities arise for foreign participation to supply products to Chinese contractors, e.g., providing financial and professional services and equipment for energy- and engineering-related projects. ${ }^{9}$

A specific example, drawing on experience with BRI projects in Pakistan, provides some context. ${ }^{10}$ Procurement of high-value China Pakistan Economic Corridor (CPEC) projects financed through the China Export-Import Bank is restricted to Chinese contractors. The Chinese CPEC authorities nominate three Chinese firms for bidding purposes. Procuring entities then issue the bidding documents to the three nominated Chinese contractors, seeking bids for the contract. Contracts may 
make allowance for domestic contractors to collaborate with Chinese counterparts via joint ventures. The processes used to select the three Chinese contractors are not made public, impeding assessment of whether the process was competitive. Whether domestic firms obtain subcontracting work is left to the Chinese contractors and the extent to which the government of Pakistan pursues "local content" objectives when negotiating BRI projects. The CPEC agreement between Pakistan and China allows for subcontracting up to a maximum of 30 percent of the contract value, but this is subject to the procuring entity's agreement. The perception of interviewees is that Chinese contractors use their own labor and that BRI procurement contracts are not very helpful in providing employment opportunities within the country. This is consistent with other assessments that even if local capacity exists, Chinese labor and equipment are generally used for BRI projects (Saalman and Dethlefsen 2017).

Although requirements in the procurement of CPEC projects to provide bank guarantees were reportedly met, amendments were made to the agreed bidding documents through addenda. These resulted from pre-bid meetings and were suggested by the three pre-selected bidders. For instance, liquidated damages for delays were reduced from 10 to 5 percent and the bonus for early completion was also changed. This is indicative of the nominated contractors' influence on the procurement process. Moreover, the Instruction to Bidder Clause describing the procuring entity's right to accept any bid and reject any or all bids was amended to make an explicit provision for negotiations. The amendment stipulates that after evaluation of bids, the technical proposal may be discussed and adjusted to obtain the desired project objectives, with any price adjustments made by mutual consent. This can constitute good practice, but in the absence of independent probity assurance for providers involved in these negotiations and the limited transparency of such discussions, this cannot be guaranteed.

A feature of BRI projects is that contracting firms in China often play a significant role in the identification and development of potential projects and may do so by shaping the public procurement agenda in favor of their areas of expertise. An absence of rules that prevent Chinese contractors from both providing feasibility studies and subsequently implementing projects; insufficient incentives to undertake consultations with potential local and international users of infrastructure facilities, both upstream and downstream, when designing projects; and contracts that reduce incentives for contractors to perform (e.g., that are limited to building the infrastructure and opposed to build-operate-transfer contracts) are all features of BRI projects analyzed by Zhu (2015), focusing on the case of Sri Lanka.

The foregoing illustrates that scope exists for improving the processes used by China and host countries to define procurement needs and award contracts. As noted below, tying financing to procurement from Chinese firms is not unique to China, but it does not constitute good practice. This applies to other dimensions of the allocation of Chinese projects as well. A feature of China's foreign policy is non-interference in 
the domestic affairs of foreign countries. One result of this policy stance is that Chinese external financial cooperation may be more open to influence by host or recipient political leaders in addressing their priorities (preferences). ${ }^{11}$ Such susceptibility to finance projects that otherwise might not be bankable is likely greater for official development assistance (grants and flows with a substantial concessional element) than other financial flows that involve borrowing (Dreher et al. 2018), which is the case for most BRI infrastructure projects. The combination of tying project financing to procurement from China, potentially greater willingness to support projects that reflect patronage politics of leaders in recipient countries, and project identification and contract award processes that are driven by Chinese firms with an interest in implementing projects, suggests that the scope for misallocation of resources and adverse outcomes is increased.

\section{China's Public Procurement Regime}

Two pieces of legislation govern public procurement in China: The Government Procurement Law (GPL) and the Bidding Law (BL). ${ }^{12}$ Since 2003, the GPL has been overseen by the Ministry of Finance. It applies to government procurement of goods, construction, and services conducted with fiscal funds at all administrative levels above certain thresholds. ${ }^{13}$ It does not pertain to SOEs, an issue that has been a key factor in GPA accession negotiations (Tu and Sun 2017). A revised GPL Implementing Regulation became effective in 2015.

Article 26 of the GPL stipulates the following procurement procedures: Public tendering, selective tendering, competitive negotiation, request for quotation, and single source procurement. The BL, which has been effective since 2000 , is overseen by the National Development and Reform Commission, and governs procurement activities of both public and private entities (including SOEs) relating to large publicly funded infrastructure works and related supplies and services. These projects can be financed or co-financed by the government, state bodies, loans, and aid funds from international organizations or foreign governments. Article 10 of the BL indicates that procurement may be on the basis of both open and selective tendering. In 2013, over 80 percent of government procurement contracts in China were allocated through open bidding procedures (Cao and Zhou 2017). Under both laws, the implementing regulations specify threshold values that determine if they apply. For individual construction contracts, the threshold in the BL is RMB 2 million; for supply contracts, RMB 1 million.

Preferential treatment of domestic over foreign enterprises is enshrined in Article 10 of the GPL, which has explicit "Buy China" provisions. Government agencies are required to source from Chinese companies unless domestic firms are at least 20 percent more costly than foreign firms. Of relevance to the BRI, the GPL provides an exception to the Buy China requirement if goods or services are for use outside 
China (Grieger 2016). Thus, the GPL does not constrain Chinese funding agencies from requiring international competitive tendering for BRI projects if a policy decision to that effect were to be taken. The BL does not explicitly require "Buy China", but provides significant scope for sub-central government bodies to exercise discretion through local content requirements, preferences for holders of indigenous patents, and exclusions of consortia. These tend to skew the process in favor of Chinese enterprises in sectors such as energy, construction, and engineering. Article 9 of the GPL and Article 6 of the Implementation Rules of the GPL provide that public procurement facilitate the achievement of goals designated by state policies. This provides broad scope for decision-making bodies to justify discriminatory award of contracts.

The upshot is that Chinese law supports the award of BRI contracts to preferred Chinese suppliers, potentially without recourse to open, competitive bidding, but at the same time there is discretion permitting agencies not to apply "Buy China" requirements to BRI procurement as this occurs outside China. Similarly, Chinese policy banks have significant scope to impose specific procurement requirements for the projects they finance, generally requiring borrowers to include the bank in their procurement processes, including bidding and tendering activities (Hoare, Hong, and Hein 2018). More broadly, foreign investment by Chinese enterprises is subject to approvals by Chinese government bodies such as the National Development and Reform Commission, the Ministry of Commerce, and the state-owned Assets Supervision Commission of the State Council. The Ministry of Commerce (MOFCOM) has a mandate to coordinate delivery of large projects in partner countries, working with relevant ministries, policy banks, and relevant SOEs. For projects that have a concessional finance element, the ministry has a mandate to oversee the associated procurement processes, creating opportunities for it to influence them (Hoare, Hong, and Hein 2018). In short, there appears to be substantial scope for Chinese government entities and financial institutions to move the public procurement process for BRI projects to be both more transparent and to rely more on competition in the award of contracts.

\section{Good Procurement Practices}

The basic features of good practices in public procurement are well known. They are embedded in the procurement guidelines used by multilateral development banks, the provisions of the WTO Government Procurement Agreement, and United Nations Commission on International Trade Law (UNCITRAL) model laws. They include ensuring transparency and encouraging the use of competition in the allocation of contracts through open tendering; measures to promote competition and prevent collusion between bidders; clarity on the evaluation criteria that will be used to determine the winning bid, whether there will be a preference given to (certain types of) domestic firms; providing feedback to bidders; and domestic 
review (complaints) mechanisms permitting firms to contest perceived noncompliance by procuring entities with procurement regulations. Contracts above a certain minimum threshold or requiring specialized technical expertise should be subject to international competitive bidding (ICB).

Transparency is critical to making firms aware of opportunities, entailing publication of notices, ensuring there is sufficient time to prepare bids, and making clear what the performance requirements are (Evenett and Hoekman 2005, 2013). Transparency is also necessary to permit firms to contest procurement decisions and assure there is accountability and integrity. Domestic review and bid protest "challenge" mechanisms are particularly important for accountability of procurement outcomes. Requirements that call for tenders be published, that bids are opened in public, that procuring entities must award contracts to the lowest bidder who satisfies the technical criteria, and so forth, are much less relevant to firms if there is no effective recourse to situations where entities do not follow the rules. Another good practice relating to transparency is to publish data on both procurement processes and outcomes to allow for ex post analysis. This is a precondition for evaluation of the effects of processes and learning about how they might be improved.

As in any area of regulation, different countries may pursue different approaches to procurement. Although there is a strong presumption that principles such as transparency and competition are important features of good procurement regimes, there is no one-size-fits-all optimal procurement mechanism that is appropriate for all situations and all countries. For procurement involving long-lived infrastructure projects, new technologies, or outsourcing of public services, learning from experience through feedback mechanisms and international cooperation is of great importance. For example, until relatively recently, the basic presumption in the procurement literature was that the type of arms-length international competitive bidding procedures regarded as good practice would, as a rule of thumb, generate efficient outcomes by awarding contracts to the lowest cost supplier able to meet the technical project requirements. For more complex projects, efficiency may call for procuring entities to engage in negotiations and to interact with potential suppliers (see Spiller 2009). Such "competitive dialogue" permits companies to engage with procuring entities, allows the latter to consider alternative solutions and technologies, and to determine what would be most appropriate in addressing their specific needs. Another good practice is to incorporate "benchmarking" of costs into the process, i.e., comparing the cost of bids for projects with the costs of similar projects that have equivalent technical requirements and quality standards.

There is extensive empirical evidence that good procurement practices improve outcomes by increasing competition and lowering procurement prices. For example, Kenny and Crisman (2016) use data on over 65,000 World Bank works contracts and find that rules requiring advertising of procurement opportunities have a positive impact on bidding levels. Coviello and Mariniello (2014) estimate that tender 
publication requirements in Italy for above-threshold contracts induce entry and reduce the costs of procurement substantially. Knack, Biletska, and Kacker (2019), using enterprise data for 88 countries, find that firms are more likely to participate in public procurement markets in countries with more transparent procurement systems that rely more on open competition. Similarly, Ghossein, Islam, and Saliola (2018), using data for 109 economies and 59,000 firms confirm that countries with better public procurement quality observe more participation in public procurement markets. Lewis-Faupel et al. (2016) find that the use of electronic procurement improved infrastructure provision in India and Indonesia. Djankov et al. (2017) obtain the same result for a broad cross-section of developing countries.

\section{Multi-Country and Cross-Border Infrastructure Projects}

An important dimension of the BRI is that it is a multi-country initiative spanning regions and transport corridors that improve the connectivity between BRI countries. Most of the financing involved comes from loans from China's policy banks and trade credits for contractors. Regional projects that improve connectivity can have high rates of return, both financial (pecuniary) and social (nonpecuniary), by reducing trade and transport costs for people and firms on both sides of a border. Cross-country projects are inherently more complex than stand-alone projects within a country. Because multiple governments and associated stakeholders are affected it is important that such projects are well designed and clearly identify the size of associated benefits and costs, both economic and non-economic.

Cooperation on market integration-related projects may have some characteristics of regional public goods (Estevadeordal, Frantz, and Nguyen 2004) but often regional infrastructure comprises club goods in that benefits are excludable and the distribution of project costs can be allocated based on the estimated incidence of benefits. In principle, cooperation on cross-border projects to produce club goods does not give rise to free rider problems (Sandler 2010), but if the distribution of benefits and location of costs is very asymmetric this must be addressed in the project design. A regional project may generate investment obligations that are disproportionately located in one country. If so, a small country with limited borrowing capacity may not be able to contribute the needed magnitude of financing. Conversely, regional cooperation may be impeded because of large disparities in the distribution of payoffs. Such "capacity problems" can impede regional projects from being realized. Even with burden-sharing and co-financing, small countries where investments would need to occur may not be able to mobilize the required resources.

In practice, preferences and priorities may differ across countries; there may be uncertainty about project costs and benefits and their distribution, disagreements about cost sharing, and fears of exploitation of market power once a regional infrastructure investment has been realized. Good practices for multi-country projects include 
establishing a coordinating mechanism that brings together all relevant stakeholders, agreeing on a common vision, mobilizing and sustaining the needed political support in participating countries, and putting in place a clear legal and contractual framework to govern the collaboration (Baird and Barker 2018). Large multi-country infrastructure projects will generally call for a mix of funding. Grants and concessional funding may be needed to address capacity or financial weaknesses of participating developing countries, support project preparation, or develop needed regulatory instruments and related "software" (Kuroda, Kawai, and Nangia 2008). Regional infrastructure projects must include a management function that is assigned responsibility to implement and operate. Even if burden-sharing for the needed investments in hardware can be agreed among the countries involved, countries are often reluctant to borrow to finance the management function and to meet related capacity-building requirements (Hoekman and Njinkeu 2012).

WEF and Boston Consulting (2014) present a best practice framework for the management of multi-country infrastructure projects. ${ }^{14}$ This includes anchoring projects in the national development plans of the countries concerned and coordinating with the various multilateral and bilateral agencies that are active in a region (e.g., the African Union Commission, the New Economic Partnership for Africa and the African Development Bank in Africa); and generating bankable feasibility studies that include determination of the costs, benefits (pecuniary and nonpecuniary), and risks, as well as their incidence across countries or entities. This must include a detailed compensation plan for people and communities that will be adversely affected. In terms of procurement, competitive and transparent tendering and contract award processes are critical, as is the development of an appropriate financing structure and risk mitigation instruments. Four specific best practices are identified: (a) Establish a procurement committee that includes neutral experts; (b) establish regional financing instruments, working with regional and multilateral agencies; (c) leverage risk mitigating guarantees to reduce political risk for investors-e.g., by utilizing the insurance services provided by Multilateral Investment Guarantee Agency; (d) reduce exchange rate risks by reflecting revenue currencies proportionally in the financing structure and creating financial instruments that hedge or insure against exchange rate risks.

Other good practices are to ensure procurement and project design is sensitive to the need to align technical and regulatory standards as these apply to the infrastructure itself and to the operators that will use it. Effective coordination and management are important, including in the contract implementation phase, to ensure that parts of the project interconnect as planned. This should extend over the life cycle of the project and may be best done through a special purpose public agency that has overall accountability for the project or program. This body should take responsibility for the preparation of tender documents and selection of contractors, manage and supervise implementation, as well as oversee operations and maintenance once the infrastructure has been built. 
Figure 1. Average Benchmarking Public Procurement Scores for Four Categories

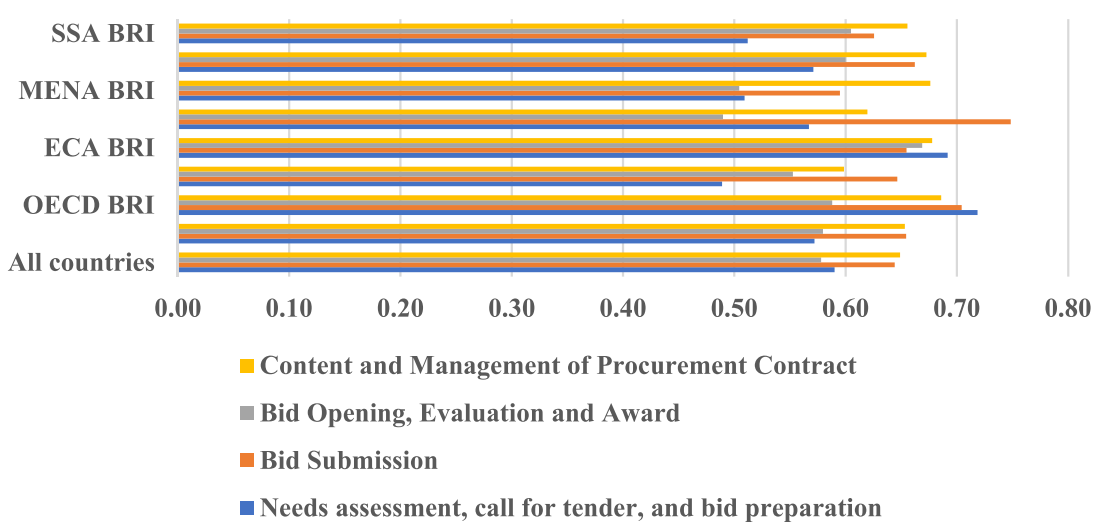

Source: World Bank (2016).

Note: Higher scores denote better practices.

A final area we will mention briefly concerns the importance of recognizing that a focus on large multi-country projects will often need to be complemented by actions that are more micro in nature. Funding small-scale cross-border infrastructure projects that leverage broader programs and larger investments to improve connectivity may be important in fully realizing the potential benefits (Carvalho et al. 2018). Such small-scale initiatives may not lend themselves to commercial financing and require grants. Often they will be limited to a specific geographical sub-region and concern specific types of activity. Such complementary projects may need to be facilitated through special proceurement regimes that are less burdensome than those that apply to large cross-border infrastructure. ${ }^{15}$

\section{Public Procurement Law and Regulation in BRI Countries}

The feasibility and possible design of initiatives to move BRI procurement closer to good practices will depend in part on the extent to which these can build on national procurement systems. If BRI countries pursue good practices in national procurement, this can provide a basis for improvement in BRI procurement processes. Particularly salient in this regard are policies towards transparency, use of online systems (e-procurement), the ability of foreign firms to participate, whether preferences are applied for local bidders, disciplines on contract management and modification, and domestic review mechanisms.

BRI countries display significant variation in the overall quality of their procurement regimes, as is to be expected given differences in their per capita incomes (fig. 1). ${ }^{16}$ In some dimensions BRI countries are similar, e.g., most BRI countries use 
Figure 2. Existence of Online Procurement by Region

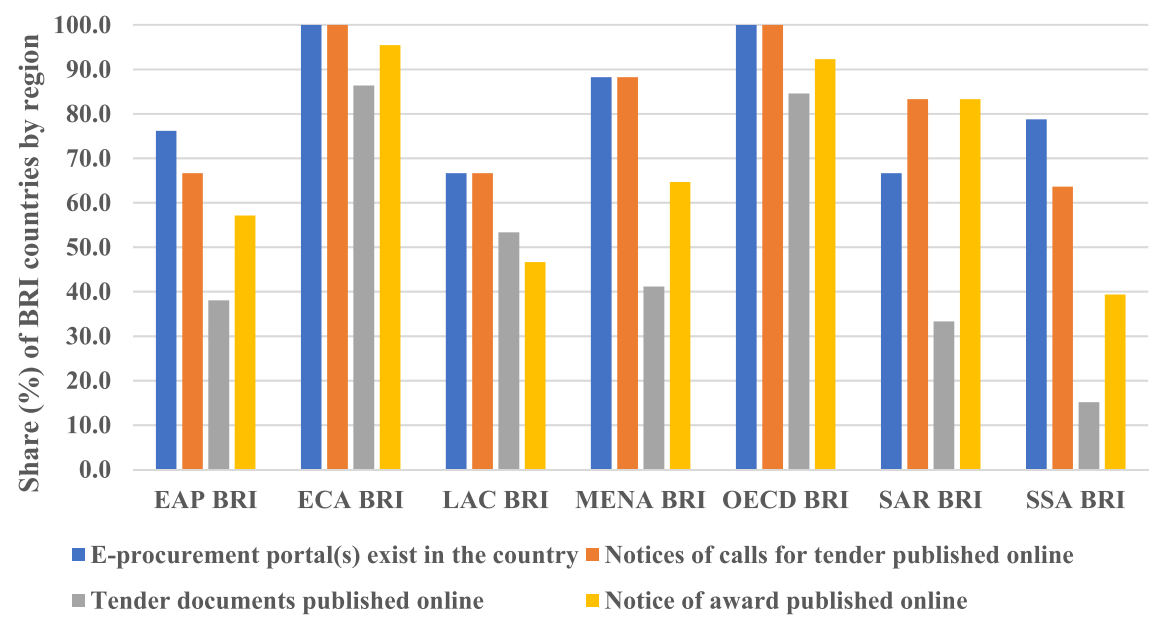

Source: World Bank (2016).

open tendering as the default method to allocate contracts. ${ }^{17}$ Many BRI countries have e-procurement systems, but in several regions these are used for only a subset of procurement opportunities, reflected in the large share of cases in which tender documents are not made available electronically (fig. 2). Availability of information on procurement opportunities, including the ability of firms to ask the procuring entity specific questions and learn what others are asking, can help all bidders provide better informed and tailored bids. In most cases ( 91 percent of BRI countries), bidders have the opportunity to ask clarifying questions and answers are shared with all bidders. In more than 60 percent of cases, BRI countries impose a timeframe for the procuring entity to address questions.

Restrictions on participation in procurement opportunities for foreign firms are common in many countries. In almost all BRI countries, foreign firms are eligible to submit bids in response to calls for tender, but there may be restrictions in terms of types or size of procurement contracts. Such limitations are observed in roughly 30 percent of all BRI countries. There is significant variation across regions in this regard (fig. 3). In some countries, the procuring entity is granted discretion whether to impose barriers and limit entry of foreign firms, but the law requires that this be specified in the notice of procurement. Examples of such provisions include set-aside programs or an obligation to supply products with only local inputs.

Another relevant attribute of procurement practices in BRI countries is the extent to which preferences can be given to domestic firms over foreign firms. The underlying goal motivating such provisions is usually a desire to use government resources to support domestic employment, investment, and learning. Many countries 
Figure 3. Are Foreign Firms Eligible to Submit Bids?

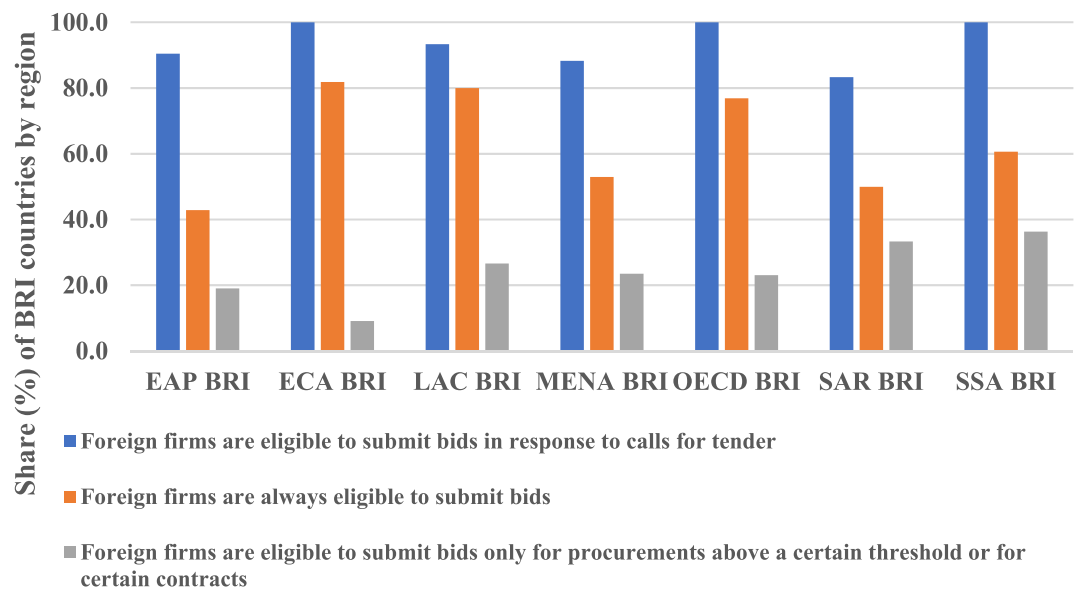

Source: World Bank (2016).

Figure 4. Domestic Preference Provisions in BRI Countries

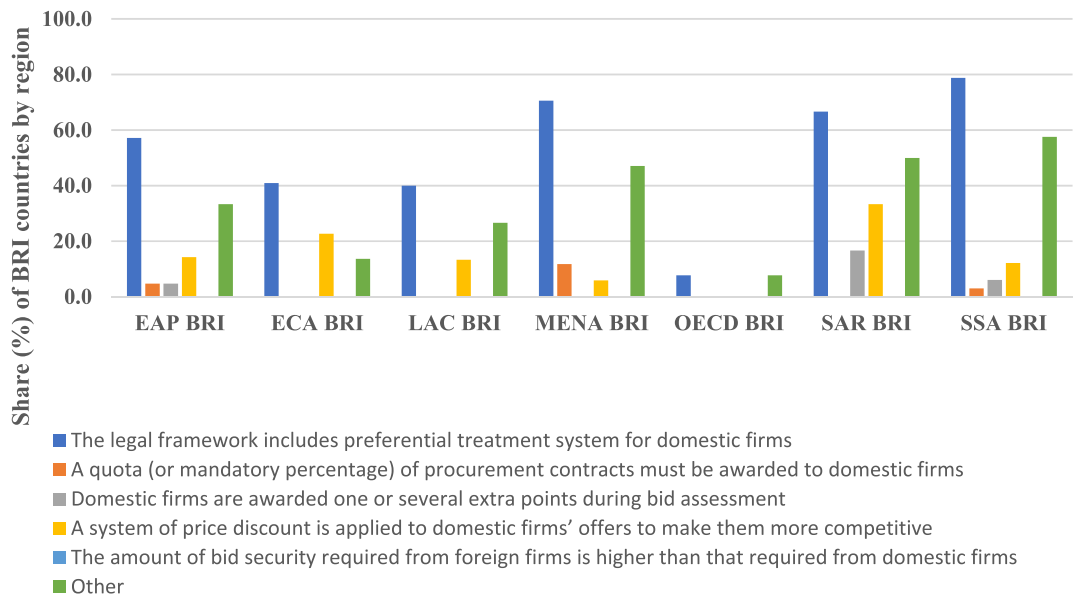

Source: World Bank (2016).

provide some form of preferential treatment to domestic firms, but there is significant variation in the method by which preferences are provided (fig. 4). Local content, subcontracting, or technology transfer requirements for foreign bidders may encourage domestic firms to invest more, expand employment, and increase productivity - in the process helping to attain industrial development objectives (Geroski 1990; Kattel and Lember 2010; Harland et al. 2019). Krasnokutskaya and Seim (2011) assess a 5 percent bid preference program for small firms in California 
and conclude this results in a substantial increase in small bidders' probabilities of participating in and winning tenders. There has been little research on the cost to the procuring entities of such programs (Nielsen 2017) but the extant literature suggests costs will be limited if the size of the preference is relatively small and if account is taken of the possibility that preferences incentivize larger (more efficient) firms to marginally reduce their bids (Marion 2007). ${ }^{18}$

Another relevant feature of good practice concerns the ability of firms to contest the decisions and behavior of procuring entities. Almost all BRI countries (96 percent) have a legal framework in place governing complaint mechanisms. Pre-award complaint systems allow procuring authorities to take corrective measures when the process is flawed or unfair. Three types of review bodies through which bidders can bring complaints are observed in BRI countries: The procuring entities themselves; independent administrative review bodies; and national courts. While there is no defined international good practice as to which should be the first-tier review body, review is usually faster and less costly when submitted before the procuring entity, especially before contracts are awarded and what is at issue is a mistake rather than a breach of public World Bank Benchmarking Public Procurement (BPP) data indicate that the higher the level of development, the more likely independent administrative review bodies will be available as an additional recourse forum for suppliers.

While national procurement practices in many BRI countries can be improved to enhance competition and transparency, many countries have regimes that are broadly aligned with international good practice. While there is substantial heterogeneity across countries on some dimensions of procurement law and practice, there is a solid basis to build on in terms of applying good practices in the BRI context.

\section{Procurement Provisions in Trade Agreements Spanning BRI Countries}

Trade agreements are an important potential instrument that BRI countries can use to move BRI procurement closer towards international good practice (Hoekman 2017). There are two types of trade agreements that can be used for this purpose: The WTO (multilateral) and preferential trade agreements (PTAs) (Anderson et al. 2011). The WTO Agreement on Government Procurement (GPA) is one of only two Plurilateral Agreements in the WTO ${ }^{19}$ It embodies what is regarded as good procurement practices by its signatories. The GPA requires non-discrimination, transparency of procurement procedures, and gives signatories access to WTO dispute settlement mechanism. It requires that notices of intended or planned procurement be published (including information on timeframe, technical requirements, and terms of payment). Price-preference policies, local content requirements, offsets, and 
Table 1. GPA Status of BRI Countries

\begin{tabular}{|c|c|c|c|c|}
\hline \multicolumn{3}{|l|}{ GPA non-members } & \multirow{2}{*}{$\begin{array}{l}\text { GPA signatory } \\
\text { Armenia }\end{array}$} & \multirow{2}{*}{$\begin{array}{l}\text { GPA observer } \\
\text { Afghanistan }\end{array}$} \\
\hline Algeria & Jamaica & Sierra Leone & & \\
\hline Angola & Kenya & Solomon Islands & Bulgaria & Bahrain \\
\hline Antigua and Barbuda & Kiribati & Somalia & Croatia & Belarus \\
\hline Azerbaijan & Kuwait & South Africa & Cyprus & Cameroon \\
\hline Bangladesh & Lao PDR & South Sudan & Czech Republic & Chile \\
\hline Barbados & Lebanon & Sudan & Estonia & Costa Rica \\
\hline Bolivia & Lesotho & Suriname & Greece & Côte d'Ivoire \\
\hline Bosnia and Herzegovina & Liberia & Tanzania & Hungary & Ecuador \\
\hline Brunei Darussalam & Libya & Timor-Leste & Italy & Indonesia \\
\hline Burundi & Madagascar & Togo & Korea, Rep. & Malaysia \\
\hline Cabo Verde & Maldives & Tonga & Latvia & Mongolia \\
\hline Cambodia & Mali & Trinidad and Tobago & Lithuania & Pakistan \\
\hline Chad & Mauritania & Tunisia & Luxembourg & Panama \\
\hline Cook Islands & Micronesia & Uganda & Malta & Philippines \\
\hline Cuba & Morocco & United Arab Emirates & Moldova & Saudi Arabia \\
\hline Djibouti & Mozambique & Uruguay & Montenegro & Seychelles \\
\hline Egypt, Arab Rep. & Myanmar & Uzbekistan & New Zealand & Sri Lanka \\
\hline El Salvador & Namibia & Vanuatu & Poland & Thailand \\
\hline Equatorial Guinea & Nepal & Venezuela, RB & Portugal & Turkey \\
\hline Ethiopia & Niger* & Yemen, Rep. & Romania & Vietnam \\
\hline Fiji & Nigeria & Zambia & Singapore & Albania* \\
\hline Gabon & Niue & Zimbabwe & Slovak Republic & China* \\
\hline Gambia, The & Papua New Guinea & - & Slovenia & Georgia* \\
\hline Ghana & Peru & - & Ukraine & Kazakhstan* \\
\hline Grenada & Qatar & - & - & Kyrgyz Republic* \\
\hline Guinea & Rwanda & - & - & North Macedonia* \\
\hline Guyana & Samoa & - & - & Oman* \\
\hline Iran, Islamic Rep. & Senegal & - & - & Russian Federation* \\
\hline Iraq & Serbia & - & - & Tajikistan* \\
\hline
\end{tabular}

Source: WTO.

Note: * In the process of negotiating accession.

similar discriminatory policies are in principle prohibited, although exceptions can be made to grandfather domestic content requirements (e.g., US federal procurement preferences for certain businesses). Developing countries may adopt or retain pricepreference policies and offset requirements on a transitional basis.

Less than a fifth of all BRI countries are members of the GPA (table 1). Membership would help promote the use of transparent, value-for-money oriented procurement processes in BRI countries regardless of their application to BRI-specific projects. China is not a member of the GPA but has been engaged in accession talks 
for over a decade, incrementally making more comprehensive offers to GPA members in terms of the coverage of sub-central entities and lowering the value thresholds determining when the agreement would apply (Tu and Sun 2017). Accession to the GPA would have direct benefits for all BRI countries and increase the likelihood that BRI projects are allocated to the most efficient, cost-competitive companies that satisfy the performance standards specified for a given project.

\section{PTAs Involving BRI Countries}

Although most BRI countries have signed PTAs, most of these do not encompass public procurement provisions. China has not included procurement in any of its PTAs, according priority to accession to the GPA (Cao and Zhou 2017), but the Comprehensive and Progressive Agreement on Trans-Pacific Partnership (CPTPP) demonstrates that PTAs can be a viable path for non-GPA members to make procurement commitments. What follows discusses the coverage of PTAs involving BRI countries.

Of 283 PTAs analyzed by Shingal and Ereshchenko (2020), 254 agreements involve at least one BRI country. Almost 50 percent of these (123) have no provisions covering government procurement. In another 63 PTAs (22 percent), government procurement is included but provisions are "shallow" in that they are not enforceable. Meanwhile 68 of these 254 PTAs ( 27 percent) include specific legally binding commitments on procurement and we refer to these as Deep Procurement Agreements (DPAs) in this analysis. The full list of PTAs involving BRI countries is reported in appendix A1. A further breakdown of these 254 agreements reveals that nearly threefifths of PTAs negotiated between BRI countries ( 85 out of 146) do not have any provisions covering government procurement; in another 33 agreements, the coverage is shallow; and 28 are DPAs (fig. 5). The distribution of procurement-coverage in PTAs that involve only one BRI country is more even: 35 percent (38 out of 108) agreements do not cover government procurement; in another 28 percent (30 PTAs), the coverage is shallow; and the remaining 37 percent (40 PTAs) are DPAs. Thus, a majority of the DPAs that have been concluded involve only one BRI country. On the whole, most PTAs involving BRI countries with deep coverage of procurement include either Chile, Singapore, or the EU (see appendix A1 for details).

Of interest here is the degree to which the DPAs include international good practices that in principle should apply to BRI projects. We consider three dimensions: Requirements prohibiting discrimination; transparency provisions; and dispute settlement. Shingal and Ereshchenko (2020) identify 14 aspects of non-discrimination that PTAs may address. Most BRI DPAs include only two-to-four non-discrimination provisions related to procurement. The most frequently observed non-discrimination provision in BRI DPAs is national treatment. Most DPAs include provisions on ex-ante and ex-post transparency. The most frequently covered transparency provisions include those related to publishing the notice of the intended or planned procurement 
Figure 5. Breakdown of PTAs Involving BRI Countries by Procurement-Coverage

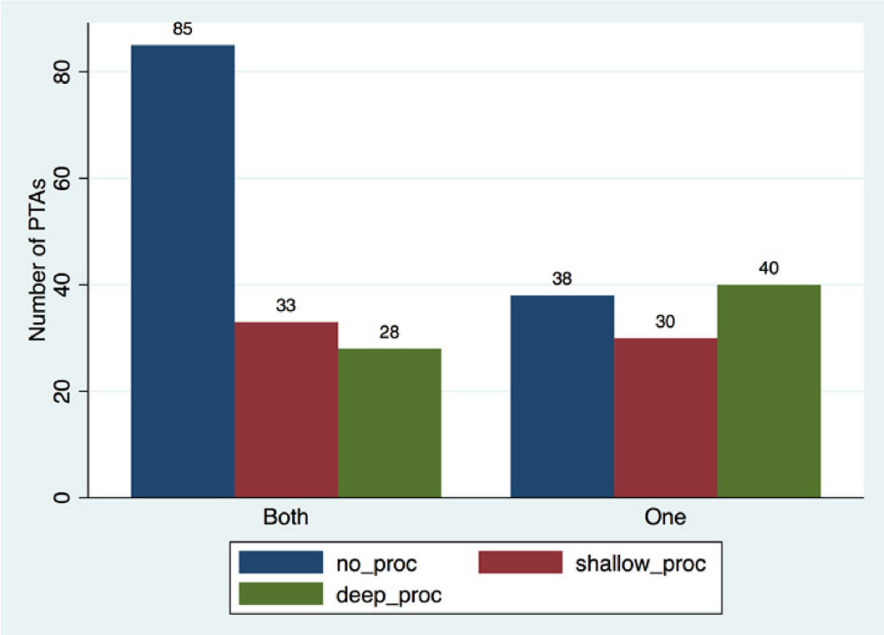

Source: Authors calculations.

Note: The left panel shows the PTA-distribution wherein both PTA members are BRI countries; in the right panel, only one of the PTA members is a BRI country.

(51/68), providing information to bidders (49/68), and publishing procurement laws and regulations (48/68; fig. 6). The least common provision relates to the collection and reporting of statistics, which is included in only seven DPAs covering BRI countries. Thus, a very important element of ex-post transparency is largely ignored by signatories involving BRI countries. Turning to enforcement and dispute settlement, most DPAs include domestic review (54/68) and provisions on dispute settlement (55/68; fig. 6).

In sum, the analysis of procurement provisions in PTAs involving BRI countries reveals that only 27 percent of the 254 agreements have a deep coverage of government procurement. Most PTAs between BRI countries do not include any provisions on government procurement. The limited participation in the GPA and absence of procurement in most PTAs suggests there is potential scope for BRI countries to consider deepening the coverage of procurement in their trade agreements as a mechanism to improve the governance of public procurement projects.

\section{Policy Options}

Although most public procurement systems aim to achieve "value for money" by requiring procuring entities to seek competitive bids for contracts above a minimum threshold value, in practice procurement is often characterized by a strong "home 
Figure 6. Transparency and Dispute Settlement Mechanisms in DPAs

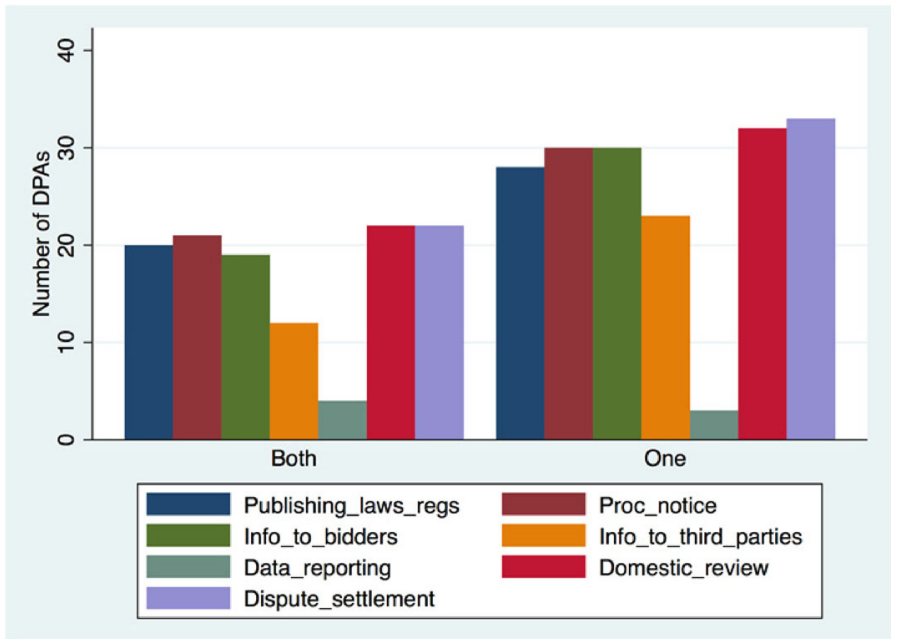

Source: Authors calculations.

Note: The left panel shows the DPA-distribution wherein both PTA members are BRI countries; in the right panel, only one of the PTA members is a BRI country.

bias": most contracts are awarded to national companies (Evenett and Hoekman 2005; Shingal 2015). This reflects preferences by governments to spend domestic tax revenues at home as well as the pursuit of economic development or social objectives (e.g., to support small and medium-sized enterprises, minorities, or disadvantaged communities) (Breton and Salmon 1995).

There is nothing remarkable about earmarking the award of BRI projects funded by Chinese entities to Chinese firms. Other countries do the same. Thus, financing from national export-import banks or export credit guarantee institutions generally is earmarked for national companies, given the preferential or concessional nature of the associated financial support. The question is whether this constitutes good practice. In the development finance context, many countries have agreed that the answer is no. This is reflected in the 2005 Paris Declaration on Aid Effectiveness calling on donor countries to move away from tying aid to sourcing goods and services from national firms. A similar decision by China regarding the BRI would provide greater assurance that BRI procurement awards go to the firms best placed to execute a project. Given the competitive strengths demonstrated by Chinese companies in procurement contests around the world, this may not in practice result in a major shift in the share of contracts going to Chinese firms, but it would provide greater assurance that winning firms are in fact those that have put forward the strongest bids. 
Efforts to improve BRI procurement practices can follow four complementary tracks. One involves action by China. Another involves actions by borrowing (host) countries in which projects are implemented. A third is to use international agreements as a commitment mechanism (Maggi 2014) to apply jointly agreed good public procurement processes. A fourth is to cooperate in providing and sharing information on procurement dimensions of BRI projects.

\section{China}

A unilateral decision that Chinese-funded BRI projects exceeding a certain value threshold will be open to international competitive bidding (ICB) is perhaps the most straightforward action that can be taken by China. ${ }^{20} \mathrm{~A}$ decision to this effect will have an additional advantage of facilitating participation by multilateral development banks (MDBs) in BRI-related projects. To date, the role of MDBs in the overall BRI has been very limited. Applying ICB to BRI projects will facilitate cooperation with the MDBs as this is a central feature of their procurement regulations for large projects and one that would apply to any future co-funded projects.

A less far-reaching option would be to require BRI projects above a specified value threshold be awarded through open internal competition among Chinese companies (including foreign-invested enterprises). This is second best from an economic efficiency perspective, as it is not necessarily the case that China-domiciled firms will offer the best price-quality offer, but open competition would be an improvement over the limited and selective tendering procedures that appear to be used frequently in the BRI context. A process limited to opening up intra-China competition arguably is also second best from the perspective of realizing the vision and underlying foreign policy objectives that motivate the BRI insofar as it may lower the credibility of the claim that the BRI's aim is to promote economic development and international cooperation. That said, starting with a greater emphasis on open competition is not a very big step in terms of moving away from the applicable domestic law and regulation of procurement given that, as mentioned previously, open bidding is supposed to be the norm in public procurement tenders in China. While a general challenge is that SOEs and sub-central governments account for most infrastructure spending - the central government accounts for only 5 percent of total procurement (Grieger 2016) —what matters for BRI projects are the processes applied by Chinese funding entities, as they have significant scope to impose specific procurement requirements.

\section{Other BRI Countries}

Borrowing countries can seek to apply national laws and regulations to BRI procurement; insist on competitive bidding (open tendering) for BRIs project that they borrow funds for to finance; or negotiate offsets and set local content targets as part of BRI 
projects in which they agree to participate. Projects, for example, can be framed to include incentives for considering subcontracting to local firms. In fact, many countries include provisions to this effect in their procurement regulations. This may not be efficient - in principle it may be better for the government to address factors that impede the ability of local firms to participate in procurement opportunities (Evenett and Hoekman 2013) — but inclusion of "local content" elements in BRI projects can be used to expand participation of domestic firms in BRI contracts.

More generally, a push towards the use of host countries' national procurement systems can be considered in instances where these systems align with international good practices and adhere to recognized core principles such as value for money, transparency, efficiency, integrity, economy, and fit-for-purpose. In practice, however, as demonstrated by the brief review of national procurement regimes in BRI countries in the previous section, these may not fully conform to international good practice in some countries. A first step could be to use diagnostics pertaining to national procurement systems' "readiness" with pre-tendering due diligence- such as those in the World Bank BPP database-before deciding which procurement rules to apply. Notwithstanding its limitation in thematic scope-it does not cover all the relevant dimensions of procurement processes - the BPP database presents a good tool to identify shortcomings in national procurement systems. By providing a crosscomparative analysis, it could promote peer-to-peer learning and identify successful reform stories, especially when it comes to BRI-related practices.

Both China and its BRI partner countries are interested in using the BRI to promote national (or local) economic activity. This gives rise to potential tension between what the different parties want. For BRI countries there is a presumption that BRI projects will promote national development prospects by improving connectivity through infrastructure improvements, although this obviously depends on whether the projects address priority constraints and the quality of the social and economic cost-benefit analysis that underpins the decision to borrow for a given project. Attaining value for money is an important factor in this regard, and ICB is one dimension of international best practice that will help ensure that projects are implemented at lowest possible cost.

Whether the terms of BRI cooperation can be changed by host countries is a matter for negotiation. Some countries have renegotiated the terms of BRI projects and more generally the parameters of BRI-based bilateral cooperation. Examples include the rejection by the government of Thailand of the initial financial terms and conditions proposed by China for a high-speed railway project and the renegotiation of the financial terms of the East Coast Rail Link project in Malaysia, which reduced the cost to the country by one-third (Chin 2021). In the case of Kenya, the government, working with Kenyan business and civic society groups, reportedly ensured significant local content in the construction of a railway between Mombasa and Nairobi, including all cement and employment of some 25,000 Kenyan workers; required 
additional features to allow wildlife to move across the railway line; and required measures to compensate affected communities (Chatham House 2017). While BRI countries can seek to influence the specific features of BRI projects to maximize value for money, their ability to do so may be constrained by asymmetries in power, foreign policy considerations, the extent to which a country has access to international capital markets, and the financial conditions or incentives that are on offer.

\section{International Agreements}

Trade agreements provide a potential mechanism through which governments can commit to good procurement practices. Accession to the GPA would complement possible unilateral actions to change BRI procurement practices, enhancing the credibility of decisions that move towards the application of international good practices for Chinese-funded BRI projects. The GPA provides a strong basis for transparency, both ex-ante and ex-post, and credibility of commitments given potential recourse to conflict resolution mechanisms. The latter are not limited to formal WTO dispute settlement. More important in practice are the regular meetings of the GPA committee where issues can be raised, and the GPA requirements to establish effective domestic review procedures. Since only one-third of BRI countries are GPA members, acceding to the GPA would also provide the remaining BRI countries the same-level playing field in terms of participation in bids, transparency of process, and recourse to the WTO's dispute settlement vis-à-vis procurement of BRI projects as other GPA signatories. From that perspective, the BRI could work as an incentive for non-GPA member countries to join the GPA.

Research on the effects of including procurement provisions in trade agreements has come to mixed conclusions. Some papers conclude there is only weak evidence that trade agreements reduce home bias in procurement (e.g., Rickard and Kono 2014). Recent research using fine-grained data on procurement contract awards suggests DPAs increase the probability that foreign firms win contracts-e.g., Taş et al. (2019) for the EU and Fronk (2015) for the US. Going beyond the effects on home bias, Dengler and Hoekman (2018) provide some evidence that trade agreements can act as a commitment device. Anderson et al. (2011) and Woolcock (2013) argue that DPAs are a mechanism that support adoption of good procurement practices. Given the research discussed above on the positive effects associated with better procedures, there is a strong case that DPAs should be considered as a means to support efforts to improve procurement outcomes.

Accession to the GPA offers a prospect for aligning BRI procurement processes with international good practices. The incentives for BRI countries to join the GPA will be much increased if China joins. This is a stated objective of the Chinese government. China has been engaged in negotiations to join the GPA for more than a decade. China clearly has major export interests in this area given that its firms have become 
major players on global public procurement markets. It is also a major market itself. One issue that has impeded agreement is the prevalence of SOEs in China's economy and views by GPA members that procurement disciplines should extend to SOEs, i.e., that they be treated as state entities. SOEs argue that they operate as commercial undertakings and hence fall outside the GPA's purview. Similar concerns have been a feature of negotiations between GPA members, as many countries either have stateowned or controlled industries or have at some point in time privatized them, raising the question whether GPA disciplines continue to apply. Although the prospect of bringing GPA accession talks to closure in the near future remains uncertain, reports suggest that China has been improving its offer (WTO 2018). ${ }^{21}$ The deterioration in trade relations between China and the United States likely reduces the nearterm prospects of Chinese accession to the GPA, but, conversely, membership can also be a mechanism for China to address some of the concerns trading partners have regarding access to the Chinese market.

While most PTAs are less comprehensive than the WTO GPA in terms of coverage, PTAs can help BRI governments increase the prospects that projects are allocated to firms that are best placed to implement them in terms of value for money and quality of services provided. They can do so by providing a mechanism to promote competition between firms interested in participating in procurement opportunities. Such mechanisms are relevant even if firms located in a BRI country have limited ability to engage in procurement processes or to supply services competitively. This is because they create an avenue for foreign firms to challenge instances where projects are allocated on a non-competitive basis. ${ }^{22}$

\section{Enhancing Transparency}

It would benefit all BRI countries to have better information about the public procurement processes associated with BRI projects. The absence of comprehensive and comparable data makes it difficult to determine the effect of applied policies and processes on outcomes. Better knowledge of procurement will help in assessments of BRI projects, both at the feasibility and design stage and post implementation, helping to inform evaluation of the effectiveness of procurement processes in attaining value for money objectives.

One possibility that could be considered to enhance transparency and generate more information on BRI procurement is to mobilize resources to document the practices used in the award of projects across countries. It can be difficult for governments consistently to apply procurement procedures that are transparent, open, and competitive. Political economy pressures invariably arise that may impede implementation of international good practices or the application of the processes that are specified in national law and regulation. Multilateral cooperation among BRI countries to generate and share information can help solve this problem by providing a basis for 
assessment and learning about processes and resulting outcomes (Hoekman 2017). Greater transparency regarding procurement practices associated with BRI projects will have the added benefit of facilitating co-funding of projects with multilateral development agencies and other investors.

A BRI-focused transparency initiative could be organized as a knowledge platform that would be used as a focal point for exchange of information and learning by BRI governments and as a mechanism for greater engagement with stakeholders, including the private sector. ${ }^{23}$ Such a platform could build on databases that have been compiled by research institutes and extend these with information on the procurement processes used. It could have an operational dimension in terms of acting as the source of information on calls for tender for BRI projects, along the lines of the e-procurement systems that many governments have put in place. Given the multicountry nature of the BRI, a relevant model in this regard could be the Tenders Electronic Daily system that has been developed by the EU and that is a central depository for procurement opportunities across all the EU member states. In addition to collecting information from procuring entities on the identity of winning bidders, a BRI electronic procurement platform could bring together information on salient characteristics of project procurement such as the award procedure used; the number of bidders; whether, where, and when the call for tender was advertised publicly; whether there was a process of negotiation after selection of the winning bid or identification of eligible firms in the case of selective tenders; and the financial terms that applied.

Such a transparency mechanism could build on the Open Contracting Partnership Data Standard which enables disclosure of data and documents at all stages of the contracting process by defining a common data model (Open Contracting Partnership 2021). As a global, non-proprietary data standard structured to reflect the complete contracting cycle, it enables users and partners around the world to publish shareable, reusable, machine-readable data, to augment that data with their own information, and to create tools to analyze or share information. Adopting the open contracting data standard could help deliver better value for money for governments and drive higher-quality goods, works, and services for communities. For private suppliers, it can create fairer competition and a level playing field, especially smaller firms, hence curbing fraud and corruption.

The design, scope, and coverage of any BRI-wide procurement transparency platform will depend on what BRI countries define its objectives to be and the willingness of governments to contribute the required information and to provide the needed technical and financial resources. Such a platform can build on the investments that have been made in many BRI countries to assure transparency and use e-procurement systems. It could be managed as a joint venture and be supported by one or more international organizations (e.g., the UN Economic Commissions covering the different BRI regions). A willingness to move down this path would constitute a strong signal that the BRI countries collectively are committed to greater transparency. 
China has shown awareness of the need to improve governance and the integrity in BRI projects as reflected in statements by President Xi that China will strengthen international cooperation on anticorruption in order to build the Belt and Road Initiative with integrity (Xi 2019) and the commitments made at the second Belt and Road Forum for International Cooperation in 2019 to do more to engage in open consultations with local stakeholders, promote economic and environmental sustainability, and pursue multilateral cooperation in the implementation of the BRI (Wang and Chen 2020). These elements of what has been characterized as "BRI 2.0" (Ang 2019) are fully consistent with the suggestions to prioritize efforts to make the procurement processes associated with BRI projects more transparent and to use the GPA as an instrument to do so.

A BRI platform that acts as a mechanism to support data collection, provides the technical assistance and financial resources to do so, and is designed to encourage analysis of the effects of procurement processes can help improve knowledge of what is being done and address concerns whether and how the BRI supports sustainable development goals. China's announcement in 2018 of an International Development Cooperation Agency meant to enhance coordination and supervision of BRI projects is an important step signaling China's positive intentions in this respect (Haenle 2018).

\section{Concluding Remarks}

The BRI is a major potential source of funding for countries seeking to improve regional connectivity, complementing the resources of development finance institutions. A key feature of the initiative is that it spans over 130 countries and has an explicit focus on supporting regional integration. Given the financing requirements for large infrastructure projects and the complexity of initiatives spanning multiple countries, ensuring that interventions address social and economic priorities that generate a high rate of return is important. Significant attention has been devoted to the risks that BRI projects may exacerbate debt pressures in borrowing countries and not generate high enough returns on investment. Even if projects address shared priorities and are bankable, much depends on getting procurement right: Assuring value for money and providing opportunities for local firms and communities to contribute to the realization of projects.

Public procurement is often characterized by a strong "home bias": most contracts are awarded to national companies (Shingal 2015). This reflects preferences by governments to spend domestic tax revenues at home as well as economic development or social objectives (e.g., to support small and medium-sized enterprises (SMEs), minorities, or disadvantaged communities). In the case of BRI projects funded by Chinese financial institutions, such preferences are explicit. In itself there is nothing surprising or distinct about China's approach to earmarking BRI projects funded 
by Chinese entities for Chinese firms. Other countries do the same. Financing from national export-import banks or export credit guarantee institutions generally is earmarked for national companies given the preferential or concessional nature of the associated financial support.

From a value-for-money perspective, earmarking can be costly if it implies less competitive contract awards and higher project costs, or excludes firms with the best technology and implementation capacities or local firms that can provide services efficiently. Actions to increase competition among potential suppliers and to enhance the ability of local firms to participate would benefit all BRI parties by increasing the prospect that projects are sustainable. Requiring open competition is consistent with Chinese procurement law, and Chinese policy finance institutions have substantial discretion in determining the procurement procedures to be followed by entities or projects that they fund. ${ }^{24}$

The basic features of what constitutes international good practice in procurement are well understood. Consistently implementing them is often difficult given political economy forces that may result in the non-application of good practice. This helps explain the heterogeneity in national procurement systems that is revealed by the World Bank Benchmarking Public Procurement data discussed previously. But these data also reveal a lot of progress has been made to improve procurement standards in many BRI countries. Greater use of trade agreements as a commitment device and focal point for procurement policy can help countries to move further towards good practices (Anderson et al. 2011; Woolcock 2013). Concerted actions to improve transparency are a means to both constrain rent-seeking behavior and to learn from experience. Joining the GPA and leveraging existing PTAs to include a focus on procurement can help address political economy-related constraints that may impede unilateral actions to improve procurement practices. The GPA provides a strong basis for transparency, both ex-ante and ex-post, and open, competitive procurement systems.

Putting in place a common BRI-wide mechanism to increase transparency can help identify procurement problems and opportunities to improve processes. Assessing the extent to which changes in processes can improve procurement outcomesreduce project costs, enhance integrity, etc.-requires better information on how BRI projects are awarded across the range of participating countries. Collecting and analyzing such information can build on the experience of governments, regional entities (e.g., the EU), and development finance institutions in the procurement area. A necessary condition is a willingness to require procuring entities to cooperate and share information, and a concerted effort to mobilize the resources required to compile and process data into a common format and make this available through an online platform.

The magnitude of the financial investments that are envisaged under the umbrella of the BRI, its importance as a central pillar of China's foreign policy, and the role 
the BRI can play in fostering regional integration imply that the opportunity costs of the status quo-limited information and transparency regarding BRI procurement processes - are significant. Pursuit of a joint effort to report, compile, and analyze information on BRI procurement processes is a straightforward way to help assess, and where necessary, enhance BRI procurement governance. Doing so can have significant positive spillover effects on public procurement more broadly, by fostering learning among stakeholders within and across the regions spanned by the BRI, and also facilitate economic recovery in the aftermath of the COVID-19 pandemic, especially given the sharp decline in both trade and investment across the world.

\section{Notes}

bernard.hoekman@eui.eu (corresponding author), tghossein@ifc.org; anirudh.shingal@spjimr.org. The authors are grateful to the reviewers, Peter Lanjouw, Elmas Arisoy, Subhashini Abeysinghe, Kofi Awanyo, Bekele Debele, Caroline Freund, Bert Hofman, William Nielsen, Michele Ruta, Kalpana Tokas and Xinquan Tu for assistance, comments and suggestions. The preparation of this paper was supported by the World Bank (Shingal) and the European Union Horizon 2020 research and innovation program under grant agreement No. 770680 (Hoekman). The views are personal and should not be attributed to the World Bank Group.

1. BRI partner countries are spread all over the world, with 34 confirmed participating countries in Sub-Saharan Africa; 32 in Europe and Central Asia (including 17 EU Member States); 25 in East Asia and the Pacific; 17 in the Middle East and North Africa; 17 in Latin America and the Caribbean; and 6 countries in South East Asia (Nedopil 2020).

2. See, for example, Hurley, Morris, and Portelance (2018) and World Bank (2019).

3. Bank of China, Industrial \& Commercial Bank of China, and China Construction Bank are the leading players ( Liu, Zhang and Xiong 2020).

4. See, e.g., the discussion in Shah (2018) and Rana (2015) on procurement of BRI projects in Pakistan.

5. See Ang (2019) for an excellent discussion of the nature of the initiative, arguing that it is not a "top-down" organized and implemented program but is more an umbrella under which different entities can pursue their own projects without much in the way of coordination.

6. Even in the larger sample of 138 projects where the source of funding was reported but not the amount, 109 projects, i.e., close to 80 percent, had Chinese firms as contractors. In fact, the allocation of Chinese-funded BRI projects to Chinese firms has become more pronounced over time.

7. Implicit preferences may arise as a corollary of the procurement process, e.g., foreign firms having more difficulty in obtaining timely and accurate information relative to Chinese firms, which affects their ability to submit bids on time.

8. In the case of concessional loans, China Export-Import Bank rules state that "Chinese enterprises should be selected as contractors/exporters and equipment, materials, technology or services needed for the project should be procured from China ahead of other countries-no less than 50 percent of the procurement shall come from China" (Davies et al. 2008, 57). Many Chinese grants and loans are tradefinance instruments, e.g., export credits for Chinese firms and financing of firms in importing countries to buy goods and services from Chinese firms (Dreher et al. 2019).

9. For instance, for projects in the China-Pakistan Economic Corridor (CPEC) General Electric has supplied power-plant related equipment (Wijeratne, Rathbone, and Wong 2018). 
10. What follows draws on information provided by William Nielsen (Cornell University), interviews with Pakistani implementing/government agencies as well as information provided on the CPEC website at http://cpec.gov.pk/index.

11. Dreher et al. (2019) find that the birth places/regions and ethnic groups of political leaders receive larger amounts of Chinese aid, a result that does not obtain for the portfolio of projects of the World Bank.

12. See Grieger (2016), European Commission (2017), Cao and Zhou (2017), and Tu and Sun (2017).

13. Military procurement is not subject to the GPL.

14. Other discussions of good practices for large multi-country projects can be found in Estevadeordal et al. (2004), Kuroda et al. (2008), and Baird and Barker (2018). There is no comprehensive guide to good practices for multi-country infrastructure projects.

15. Carvalho et al. (2018) provide an extensive up-to-date review of the literaure on regional infrastructure cooperation structures in Europe and policy options to facilitate cross-border transport projects.

16. The discussion in this section uses the World Bank's Benchmarking Public Procurement (BPP) database (World Bank 2016).

17. "Open tendering" is a method of procurement involving public and unrestricted solicitation under which all interested suppliers can submit a bid. BRI countries in East Asia and the Pacific lag behind other regions on this measure.

18. Empirical research has found participation in procurement by smaller local firms can have a positive effect on their performance. See Hoekman and Sanfilippo (2020) for discussion of the relevant literature on this subject and Hoekman and Taş (2020) for evidence for the European Economic Area.

19. WTO members are free to discriminate against foreign products when buying products for public consumption if they decide not to sign the GPA. At the time of writing, there are 48 parties to the GPA, including the 27 members of the EU and the UK. See Anderson et al. (2011) and Davies (2017).

20. The applicable thresholds could be based on (a multiple of) those that apply in the Government Procurement Law and the Bidding Law to domestic procurement.

21. https://www.wto.org/english/news_e/news18_e/gpro_27jun18_e.htm.

22. An example of such dynamics at work was a 2017 project financed by China for a railway between Belgrade and Budapest. The procurement process was challenged by the European Commission to assess if the procedures employed were consistent with EU procurement regulations mandating open calls for tendering and competitive bidding. See Kynge (2017).

23. A potential model to learn from is the Public Procurement Knowledge Exchange Forum, an initiative started in the early 2000s, co-sponsored by the MDBs supporting countries in the Balkans and Central Asia. This aims to promote regional cooperation and mutual learning about good practice (World Bank 2015).

24. Open competitive procurement practices that do not encompass preferential treatment have been shown to encourage participation by SMEs as well as larger firms. See Hoekman and Taş (2020).

\section{References}

Abi-Habib, M. 2018. "How China Got Sri Lanka to Cough Up a Port." New York Times. June 25. https://www.nytimes.com/2018/06/25/world/asia/china-sri-lanka-port.html.

Anderson, R., C. Müller, K. Osei-Lah, J. Pardo de Leon, and P. Pelletier. 2011. "Government Procurement Provisions in Regional Trade Agreements: A Steppingstone to GPA Accession?” In The WTO Regime on Government Procurement: Challenge and Reform, edited by S. Arrowsmith and R. Anderson. Cambridge: Cambridge University Press.

Ang, Y. 2019. "Demystifying Belt and Road: The Struggle to Define China's 'Project of the Century”, Foreign Affairs, May 22. https://www.foreignaffairs.com/articles/china/2019-05-22/demystifyingbelt-and-road. 
Baird, M., and S. Barker. 2018. "Financing Cross-Border Infrastructure Projects." Six-Part Blog. https://www.gihub.org/blog/financing-cross-border-infrastructure-projects-bankability/.

Breton, A., and P. Salmon. 1995. "Are Discriminatory Procurement Policies Motivated by Protectionism?" Kyklos 49: 47-68.

Cao, F., and F. Zhou. 2017. "Internationalization of Government Procurement Law and Relevance of International Norms and Frameworks: The Case of China." In The Internationalization of Government Procurement Regulation, edited by A. Georgopoulos, B. Hoekman and P. Mavroidis. Oxford: Oxford University Press.

Carvalho, D., J. Vieira, V. Reis, and C. Frencia. 2018. New ways of financing transport infrastructure projects in Europe. Brussels: European Parliamentary Research Service.

Center for Strategic and International Studies (CSIS). 2021. "Reconnecting Asia." https://reconasia.csis. org/about/.

Chan, S. 2017. "The Belt and Road Initiative: Implications for China and East Asian Economies." Copenhagen Journal of Asian Studies 35 (2): 52-78.

Chatham House. 2017. "Lessons from Kenya's New, Chinese-funded Railway, June 20." https://www.chathamhouse.org/expert/comment/lessons-kenya-s-new-chinese-funded-railway.

Chin, K. 2021. "Malaysia's Perception and Strategy toward China's BRI Expansion: Continuity or Change?." The Chinese Economy 54 (1): 9-19.

Coviello, D., and M. Mariniello. 2014. "Publicity Requirements in Public Procurement: Evidence from a Regression Discontinuity Design.” Journal of Public Economics 109: 76-100.

Davies, A. 2017. “The Evolving GPA: Lessons of Experience and Prospects for the Future." In The Internationalization of Government Procurement Regulation, edited by A. Georgopoulos, B. Hoekman and P. Mavroidis. Oxford: Oxford University Press.

Davies, M., H. Edinger, N. Tay, and S. Naidu. 2008. How China Delivers Development Assistance to Africa. Stellenbosch, South Africa: University of Stellenbosch Centre for Chinese Studies.

Deloitte. 2018. Embracing the BRI Ecosystem in 2018: Navigating Pitfalls and Seizing Opportunities. Deloitte Insights. https://www2.deloitte.com/content/dam/insights/us/articles/4406_Belt-and-roadinitiative/4406_Embracing-the-BRI-ecosystem.pdf.

Dengler, B., and B. Hoekman. 2018. "The WTO Government Procurement Agreement as a Commitment Device: A First Appraisal.” CEPR Discussion Paper 13266, CEPR, London.

Djankov, S., T. Ghossein, A. M. Islam, and F. Saliola. 2017. "Public Procurement Regulation and Road Quality.” Policy Research Working Paper 8234, World Bank, Washington, DC.

Dreher, A., A. Fuchs, R. Hodler, B. Parks, P. Raschky, and M. Tierney. 2019. "Aid on Demand: African Leaders and the Geography of China's Foreign Assistance." Journal of Development Economics 140: $44-71$.

Dreher, A., A. Fuchs, B. Parks, P. A. Strange, and M. Tierney. 2018. "Apples and Dragon Fruits: The Determinants of Aid and Other Forms of State Financing from China to Africa." International Studies Quarterly 62 (1): 182-94.

Estevadeordal, A., B. Frantz, and T. Nguyen, eds. 2004. Regional Public Goods: From Theory to Practice. Washington, DC: InterAmerican Development Bank and Asian Development Bank.

European Commission. 2017. "Commission Staff Working Document on "Significant distortions in the economy of the People's Republic of China for the purposes of trade defence investigations." https://trade.ec.europa.eu/doclib/docs/2017/december/tradoc_156474.pdf.

Evenett, S., and B. Hoekman. 2005. "Government Procurement: Market Access, Transparency, and Multilateral Trade Rules." European Journal of Political Economy 21 (1): 163-83.

2013. "International Disciplines on Government Procurement." In Handbook of Trade Policy for Development, edited by A. Lukauskas, R. Stern and G. Zanini. Oxford: Oxford University Press. 
Fronk, J. 2015. "International Agreements on Trade in Government Procurement: Formation and Effect." PhD thesis submitted to the Faculty of the Graduate School of Arts and Sciences of Georgetown University.

Geroski, P. 1990. "Procurement policy as a tool of industrial policy." International Review of Applied Economics 4 (2): 182-98.

Ghossein, T., A. Islam, and F. Saliola. 2018. "Public Procurement and the Private Business Sector: Evidence from Firm-Level Data.” Policy Research Working Paper 8575, World Bank, Washington, DC.

Grieger, G. 2016. "Why China's Public Procurement is an EU Issue.” European Parliamentary Research Service. http://www.europarl.europa.eu/RegData/etudes/ATAG/2016/593571/EPRS ATA(2016)593571_EN.pdf.

Haenle, P. 2018. "More than a Belt, More than a Road.” https://informaconnect.com/more-than-a-beltmore-than-a-road-paul-haenle-on-the-chinese-initiative/.

Harland, C., J. Telgen, G. Callender, R. Grimm, and A. Patrucco. 2019. "Implementing Government Policy in Supply Chains: An International Coproduction Study of Public Procurement." Journal of Supply Chain Management 55 (2): 6-25.

Hillman, J. 2018. “China's Belt and Road Initiative: Five years later.” Statement before the USChina Economic and Security Review Commission. Centre for Strategic and International Studies. https://www.csis.org/analysis/chinas-belt-and-road-initiative-five-years-later-0.

Hoare, A., L. Hong, and J. Hein. 2018. "The Role of Investors in Promoting Sustainable Infrastructure Under the Belt and Road Initiative." Chatham House, May 11. https://www.chathamhouse. org/2018/05/role-investors-promoting-sustainable-infrastructure-under-belt-and-road-initiativey.

Hoekman, B. 2017. "International Cooperation on Public Procurement Regulation.” In The Internationalization of Government Procurement Regulation, edited by A. Georgopoulos, B. Hoekman and P. Mavroidis. Oxford: Oxford University Press.

Hoekman, B., and D. Njinkeu. 2012. "Aid for Trade and Export Competitiveness: New Opportunities for Africa." In Trade Infrastructure and Economic Development, edited by O. Ajakaiye and A. Oyejide. Routledge (Studies in Development Economics).

Hoekman, B., and M. Sanfilippo. 2020. "Foreign Participation in Public Procurement and Firm Performance: Evidence from Sub-Saharan Africa.” Review of World Economics 156 (1): 41-73.

Hoekman, B., and B. Taş. 2020. "Procurement Policy and SME Participation in Public Purchasing." Small Business Economics. http://link.springer.com/article/10.1007/s11187-020-00414-z.

Huang, Y. 2016. “Understanding China's Belt \& Road Initiative: Motivation, Framework and Assessment." China Economic Review 40: 314-21.

Hurley, J., S. Morris, and G. Portelance. 2018. "Examining the Debt Implications of the Belt and Road Initiative from a Policy Perspective." Policy Paper 121, Center for Global Development, Washington, DC.

Kattel, R., and V. Lember. 2010. "Public Procurement as an Industrial Policy Tool: An Option for Developing Countries?" Journal of Public Procurement 10 (3): 368-404.

Kenny, C., and B. Crisman. 2016. "Results Through Transparency: Does Publicity Lead to Better Procurement?” Working Paper 437, Center for Global Development, Washington, DC.

Knack, S., N. Biletska, and K. Kacker. 2019. "Deterring Kickbacks and Encouraging Entry in Public Procurement Markets: Evidence from Firm Surveys in 90 Developing Countries." World Bank Economic Review 33 (2): 287-309.

Krasnokutskaya, E., and K. Seim. 2011. "Bid Preference Programs and Participation in Highway Procurement Auctions." American Economic Review 101 (6): 2653-86. 
Kuroda, H., M., Kawai, and R. Nangia. 2008. “Infrastructure and Regional Cooperation.” In Rethinking Infrastructure for Development, edited by F. Bourguignon and B. Pleskovic. Washington, DC: World Bank.

Kynge, J. 2017. "EU Sets Collision Course with China over 'Silk Road' Rail Project." Financial Times. https://www.ft.com/content/003bad14-f52f-11e6-95ee-f14e55513608.

Lewis-Faupel, S., Y. Neggers, B. A. Olken, and R. Pande. 2016. "Can Electronic Procurement Improve Infrastructure Provision? Evidence from Public Works in India and Indonesia." American Economic Journal: Economic Policy 8 (3): 258-83.

Liu, W., Y. Zhang, and W. Xiong. 2020. "Financing the Belt and Road Initiative." Eurasian Geography and Economics 61 (2): 137-45.

Marion, J. 2007. "Are Bid Preferences Benign? The Effect of Small Business Subsidies in Highway Procurement Auctions." Journal of Public Economics 91 (7-8): 1591-624.

Nedopil, C. 2020. Countries of the Belt and Road Initiative. Beijing, IIGF Green BRI Center, www.greenbri.org.

Nielsen, W. 2017. "Technical Report: Policies that Promote SME Participation in Public Procurement." Business Environment Working Group (Donor Committee for Enterprise Development). https://www.enterprise-development.org/wp-content/uploads/DCED-BEWG-SME-ProcurementReport.pdf.

Maggi, G. 2014. "International Trade Agreements." In Handbook of International Economics, edited by G. Gopinath, E. Helpman and K. Rogoff. Amsterdam: Elsevier.

Open Contracting Partnership. 2021. "Open Contracting Data Standard." https://www.opencontracting.org/data/.

Rana, S. 2015. "Govt Green-lights Three CPEC Projects at 23\% Higher Cost." The Express Tribune, December 14. https://tribune.com.pk/story/1010145/cleared-in-haste-govt-green-lights-three-cpecprojects-at-23-higher-cost/.

Rickard, S., and D. Kono. 2014. "Think Globally, Buy Locally: International Agreements and Government Procurement." Review of International Organizations 9 (3): 333-52.

Saalman, L., and K. Dethlefsen. 2017. Following the forum: China's Belt and Road Initiative and the EU. Singapore: Friedrich Ebert Stiftung. http://library.fes.de/pdf-files/bueros/singapur/13565.pdf.

Sandler, T. 2010. "Overcoming Global and Regional Collective Action Impediments." Global Policy 1 (1): $40-50$.

Shah, A. 2018. "How Does China-Pakistan Economic Corridor Show the Limitations of China's 'One Belt One Road' Model." Asia \& the Pacific Policy Studies 5 (2): 378-85.

Shingal, A. 2015. "Econometric Analyses of Home Bias in Government Procurement." Review of International Economics 23 (1): 188-219.

Shingal, A., and V. Ereshchenko. 2020. "Public procurement." In Handbook of Deep Trade Agreements, edited by A. Mattoo, N. Rocha and M. Ruta. Washington, DC: World Bank.

Spiller, P. 2009. “An Institutional Theory of Public Contracts: Regulatory Implications.” In Regulation, Deregulation, Reregulation: Institutional Perspectives, edited by C. Menard and M. Ghertman. Cheltenham: Edward Elgar.

Taş, B., K. Dawar, P. Holmes, and S. Togan. 2019. "Does the WTO Government Procurement Agreement deliver what it promises?" World Trade Review 18 (4): 609-34.

Tu, X., and N. Sun. 2017. "Government Procurement in TPP and Its Implications for China's GPA Accession Negotiation." In Paradigm Shift in International Economic Law Rule-Making, edited by J. Chaisse, H. Gao and C-f. Lo, Singapore: Springer Nature.

Wang, Z., and J. Chen. 2020. "BRI 2.0: Cosmetic Repairs or a Change of Course.” Journal of World Trade 54 (5): 791-812. 
Wijeratne, D., M. Rathbone, and G. Wong. 2018. "A Strategist's Guide to China's Belt and Road Initiative.” Strategy-Business, PwC. https://www.strategy-business.com/feature/A-Strategists-Guide-toChinas-Belt-and-Road-Initiative?gko=a98e0.

Woolcock, S. 2013. "Policy Diffusion in Public Procurement: The Role of Free Trade Agreements." International Negotiation 8 (1): 153-73.

World Bank. 2015. "11th Public Procurement Knowledge Exchange Forum.” https://www. worldbank.org/en/events/2015/06/09/11th-public-procurement-knowledge-exchange-forum\#4.

_ 2016. Benchmarking Public Procurement 2017: Assessing Public Procurement Regulatory Systems in 180 Economies. Washington, DC: World Bank Group.

. 2019. Belt and Road Economics: Opportunities and Risks of Transport Corridors. Washington, DC: World Bank Group.

World Economic Forum and Boston Consulting Group. 2014. Managing Transnational Infrastructure Programmes in Africa - Challenges and Best Practices. Geneva: WEF.

World Trade Organization. 2018. "Australia's Accession Negotiations for Government Procurement Pact Reach Milestone." https://www.wto.org/english/news_e/news18_e/gpro_27jun18_e.htm.

Xi, J. 2019. "Working Together to Deliver a Brighter Future for Belt and Road Cooperation." Keynote Speech. https://www.fmprc.gov.cn/mfa_eng/zxxx_662805/t1658424.shtml.

Zhang, C., and J. Gutman. 2015. "Aid Procurement and the Development of Local Industry: A Question for Africa." Institution Global Economy and Development Working Paper 88, Brookings, Washington, DC.

Zhu, X. 2015. "Demystifying the Role of Chinese Commercial Actors in the Shaping China's Foreign Assistance." Stability: International Journal of Security \& Development 4: 1-24. 


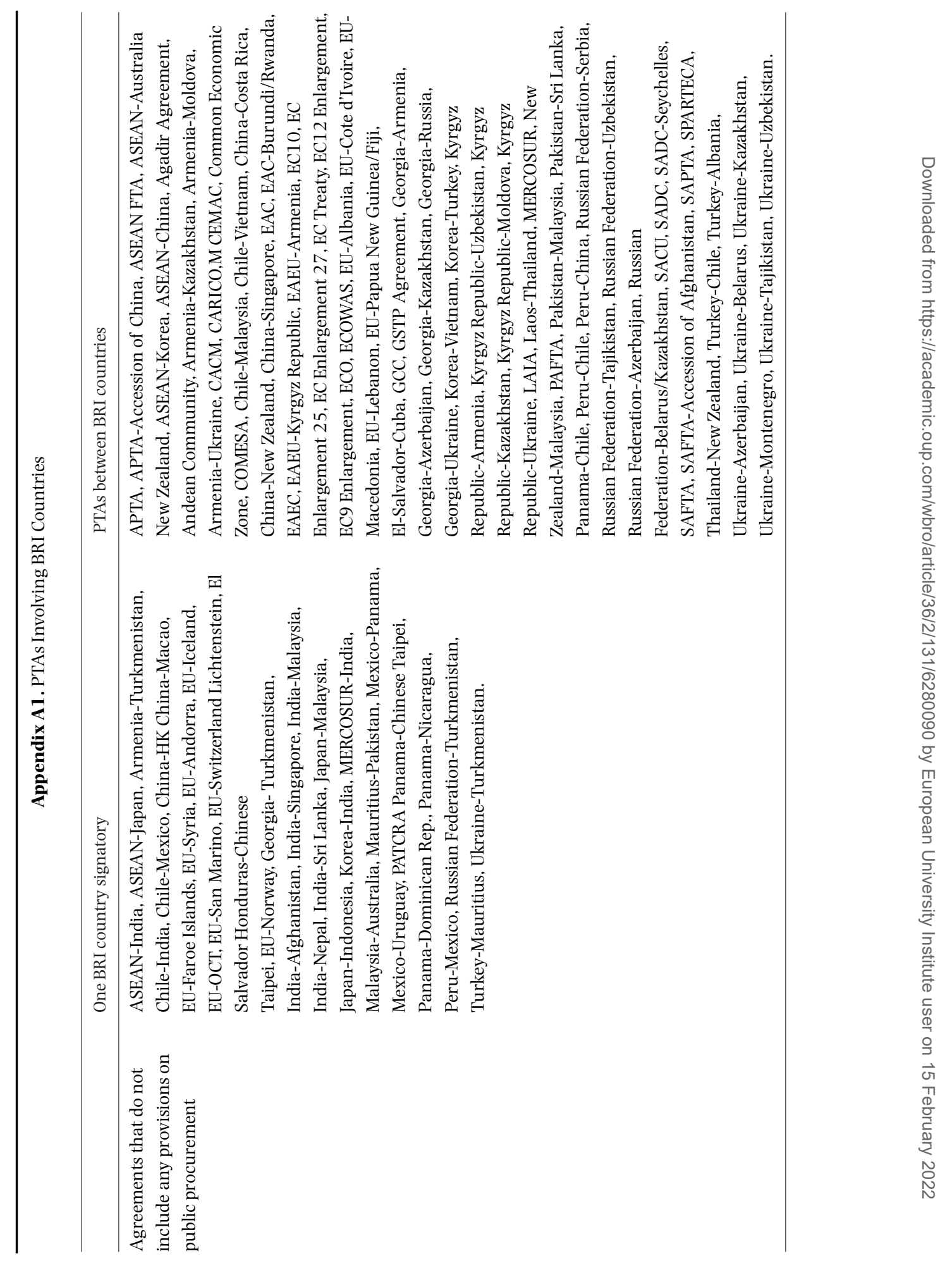




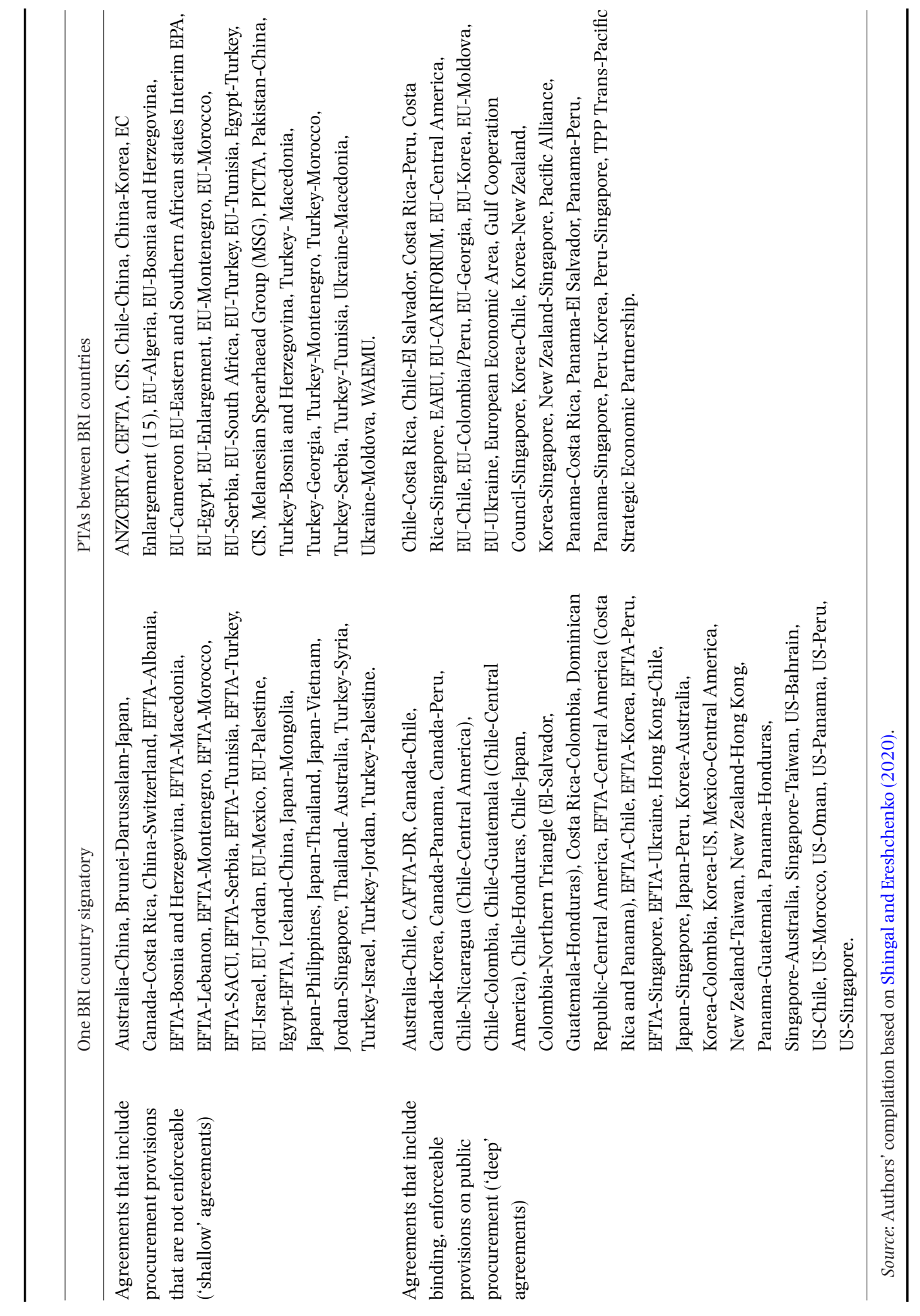

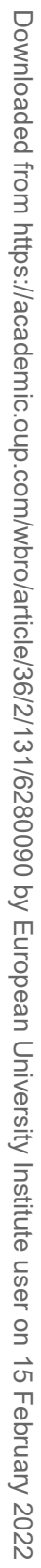

